\title{
Boreliozowe zapalenie mięśnia sercowego - antybiotyk zamiast rozrusznika
}

\author{
Lyme carditis - antibiotic instead of pacemaker
}

\author{
Monika Lica-Gorzynska, Łukasz Koziński, Zbigniew Orzałkiewicz \\ Oddział Kardiologiczny Szpitala Specjalistycznego im. J.K. Łukowicza w Chojnicach
}

\section{Streszczenie}

Przedstawiono przypadek 32-letniego mężczyzny z boreliozowym zapaleniem mięśnia sercowego i całkowitym blokiem przedsionkowo-komorowym skutecznie leczonego ceftriaksonem przez 4 tygodnie. Blok przedsionkowo-komorowy ustąpił i obecnie, po 2 latach obserwacji, pacjent pozostaje bez dolegliwości, a w 24-godzinnym monitorowaniu elektrokardiograficznym metodą Holtera nie stwierdza się zaburzeń przewodzenia przedsionkowo-komorowego.

Słowa kluczowe: choroba z Lyme, borelioza, blok przedsionkowo-komorowy

(Folia Cardiologica 2015; 10, 6: 442-447)

\section{Wstęp}

Boreliozowe zapalenie mięśnia sercowego (LC, Lyme carditis) może być jedną z manifestacji klinicznych zakażenia krętkiem Borrelia burgdorferi. Lyme carditis rozwija się na początku choroby i najczęściej jest poprzedzone objawami skórnymi w postaci rumienia wędrującego (erythema migrans), a bardzo rzadko - zmianą określana jako limfocytoma boreliozowa. Część pacjentów nie zauważa ukąszenia przez kleszcza lub bagatelizuje objawy skórne i nie zgłasza się do lekarza na wstępnym etapie choroby [1]. Typowym objawem LC są różnego stopnia zaburzenia przewodzenia przedsionkowo-komorowego; znane są przypadki LC naśladujące objawy ostrego zespołu wieńcowego [2] lub też prowadzące do upośledzenia funkcji skurczowej mięśnia lewej komory i niewydolności serca [3].

Uwzględnienie boreliozy w diagnostyce różnicowej przyczyn bloku przedsionkowo-komorowego daje szansę na zastosowanie właściwej terapii i uniknięcie niepotrzebnego wszczepienia stymulatora serca.

\section{Opis przypadku}

Mężczyzna w wieku 32 lat, z zawodu murarz, dotychczas zdrowy i bez nałogów, został skierowany do szpitala z powodu asymptomatycznej bradykardii stwierdzonej przypadkowo w trakcie zwykłej aktywności fizycznej, stanów podgorączkowych oraz obustronnych bólów stawów skokowych i kolanowych utrzymujących się od kilkunastu dni. Przy przyjęciu częstość pracy serca wynosiła 30/min, liczba oddechów - 12/min, ciśnienie tętnicze - 160/70 mm Hg symetrycznie na kończynach górnych, a temperatura ciała $-35,9^{\circ} \mathrm{C}$. Nie stwierdzono przedmiotowych cech zapalenia dużych stawów. W zapisie elektrokardiograficznym (EKG) ujawniono rytm zatokowy 90/min z blokiem przedsionkowo-komorowym III stopnia i zastępczym rytmem węzłowym 30/min (szerokość zespołów QRS 110-120 ms) oraz, okresowo, zaawansowany blok przedsionkowo-komorowy II stopnia (ryc. 1, ryc. 2). Pacjent nie zauważył ukąszenia przez kleszcza, jednak 2 tygodnie wcześniej na lewym udzie pojawił się u niego niebolesny, wyraźnie odgraniczony ru- 


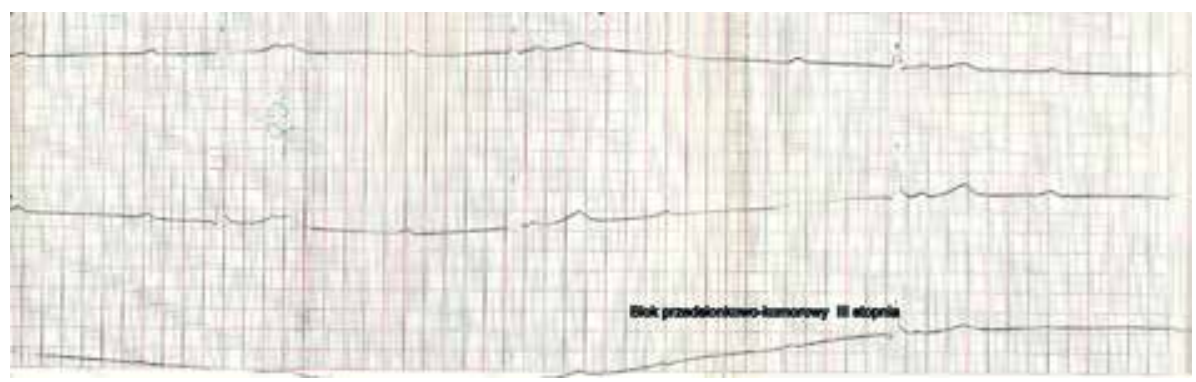

Rycina 1. Całkowity blok przedsionkowo-komorowy, przesuw papieru $50 \mathrm{~mm} / \mathrm{s}$

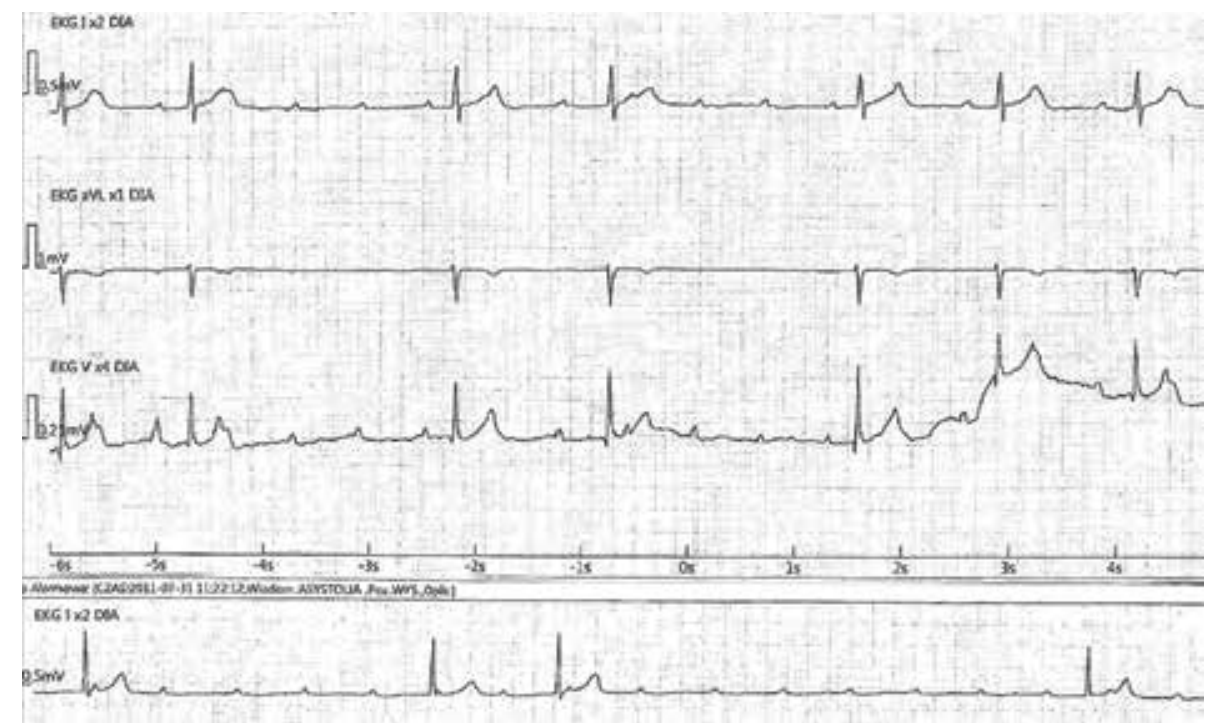

Rycina 2. Zapis elektrokardiograficzny z monitora na sali intensywnego nadzoru kardiologicznego - zaawansowany blok przedsionkowo-komorowy

mień o średnicy $10 \mathrm{~cm}$, który następnie samoistnie ustąpił po kilku dniach.

Wyniki przesiewowych testów serologicznych w kierunku boreliozy były pozytywne; wskaźnik przeciwciał lgM wynosił 188,2, a IgG - 177,4 (test metodą ELISA [enzyme-linked immunosorbent test], wyniki dodatnie, odpowiednio, $>22 \mathrm{i}>15$ ). Te wstępne wyniki potwierdzono metoda Western blot. Jeszcze przed uzyskaniem wyników badań serologicznych, czyli od 1. doby hospitalizacji, zastosowano antybiotyk (ceftriakson w dawce $2 \mathrm{~g} / \mathrm{d}$. dożylnie), którego podawanie kontynuowano przez 4 tygodnie. W 2. dobie leczenia blok przedsionkowo-komorowy III stopnia ustąpił; pozostał blok przedsionkowo-komorowy I stopnia z odstępem PQ 0,5 s (ryc. 3, ryc. 4). Od 3. tygodnia leczenia nie rejestrowano zaburzeń przewodzenia przedsionkowo-komorowego. W badaniu echokardiograficznym stwierdzono prawidłową funkcję skurczową lewej komory.

W trwającej 2 lata obserwacji pacjent potwierdzał dobre samopoczucie, a w EKG (standardowym i 24-godz. metoda Holtera) nie wykryto zaburzeń przewodzenia przedsionkowo-komorowego.

\section{Omówienie}

Borelioza z Lyme jest wieloukładową chorobą spowodowaną zakażeniem krętkiem Borrelia burgdorferi sensu lato. Bakterie są przenoszone przez kleszcze Ixodes ricinus. W latach 80. XX wieku zauważono, że w trakcie choroby może wystąpić zapalenie mięśnia sercowego [4]. Lyme carditis rozwija się w tak zwanej wczesnej rozsianej fazie choroby, średnio w 3. tygodniu od początku zakażenia, chociaż rozpiętość czasowa objawów waha się od 7 dni do około 7 miesięcy [5]. Według danych europejskich dzieje się tak w niewielkim odsetku zakażeń (0,5-4\%), natomiast w Stanach Zjednoczonych nawet u co 10. pacjenta z boreliozą rozpoznaje się w jej przebiegu LC. Tę różnicę tłumaczy się dwojako; część badaczy uważa, że w Ameryce Północnej kleszcze zakażone są krętkiem Borrelia burgdorferii w ścisłym znaczeniu gatunkowym, natomiast w Europie część kleszczy jest wektorem dla Borrelia afzelii i Borrelia garinii - niepowodujących zapalenia mięśnia sercowego. Druga przyczyna może wynikać z przyjętych w przeszłości w Stanach Zjednoczonych kryteriów rozpoznawania LC. 


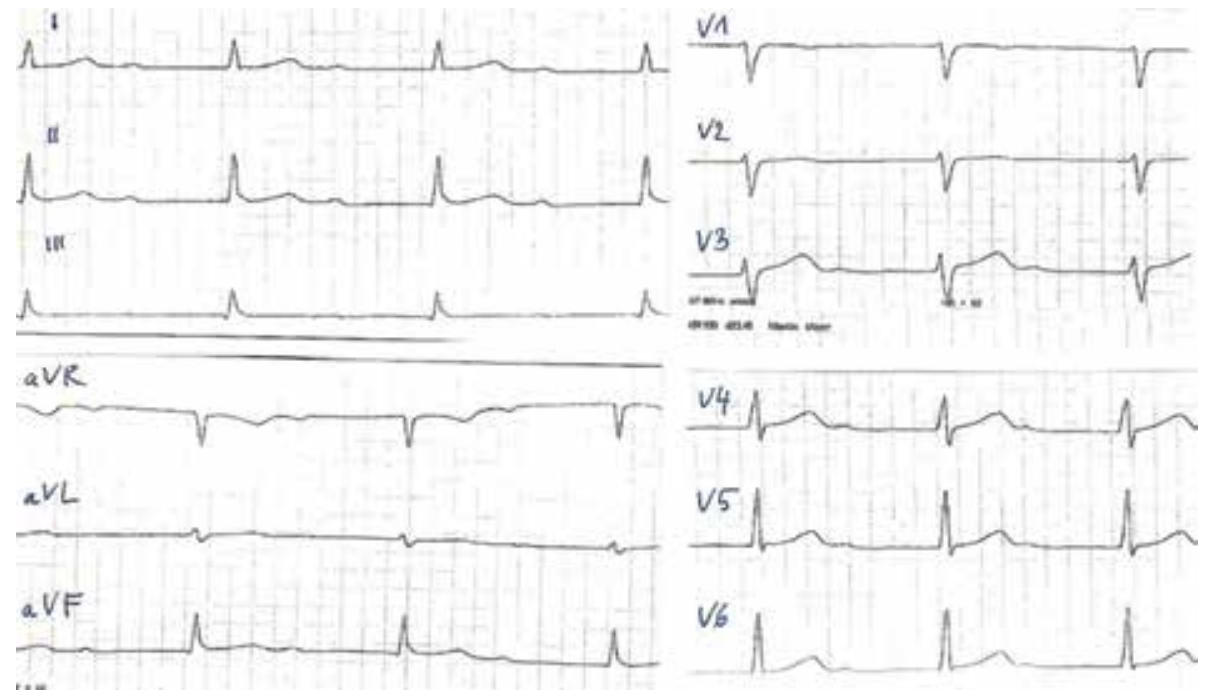

Rycina 3. Blok przedsionkowo-komorowy I stopnia z odstępem PQ wynoszącym 0,5 s - zapis elektrokardiograficzny po kilku dniach leczenia ceftriaksonem, przesuw papieru $50 \mathrm{~mm} / \mathrm{s}$

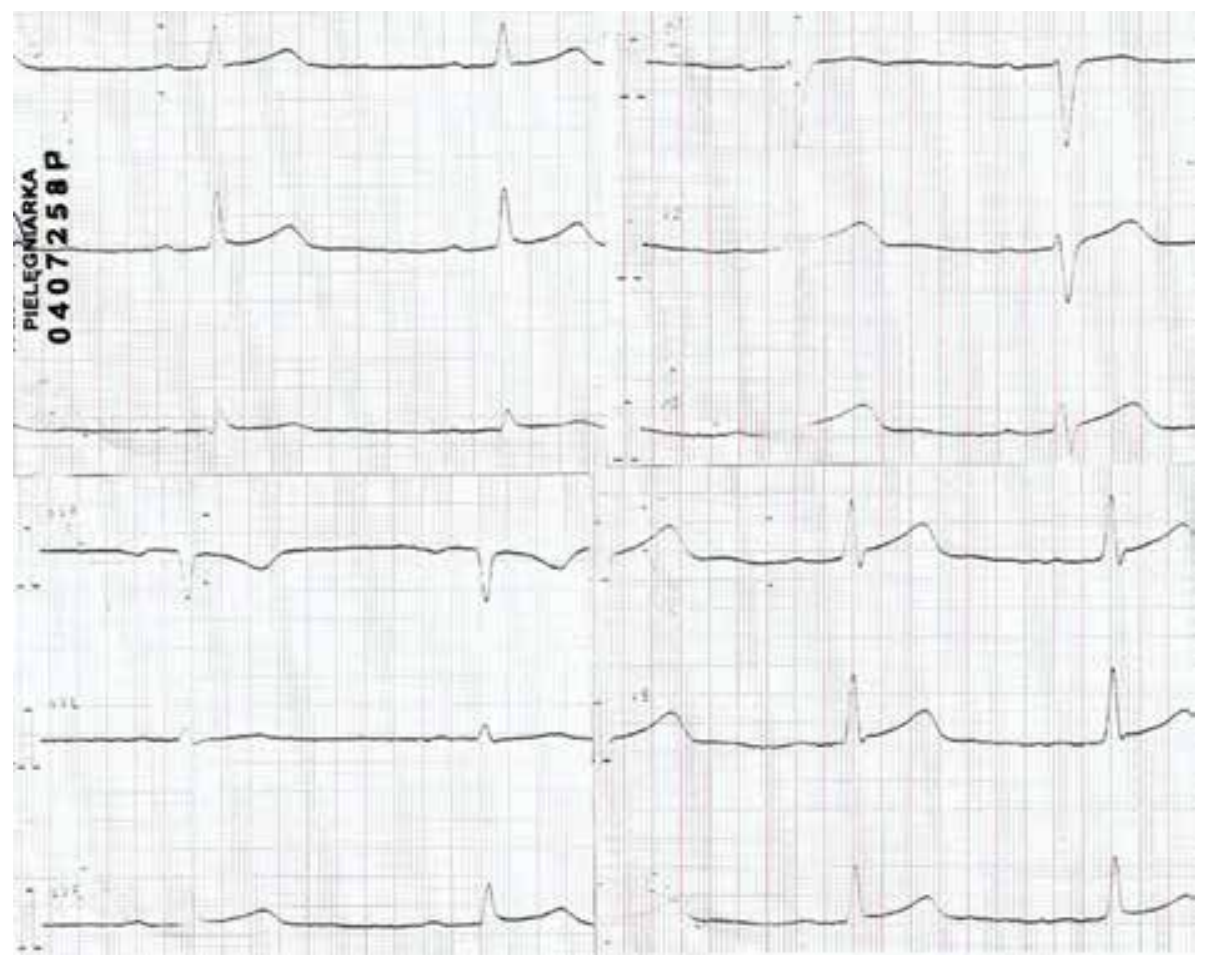

Rycina 4. Zapis elektrokardiograficzny w 3. tygodniu antybiotykoterapii - graniczny odstęp PQ wynoszący 200 ms, przesuw papieru 50 mm/s

Pozwalały one uznać mało swoiste objawy, na przykład kołatania serca, jako dowód zajęcia serca [6].

Lyme carditis najczęściej objawia się różnego stopnia zaburzeniami przewodzenia przedsionkowo-komorowego. W połowie przypadków jest to blok przedsionkowo-komorowy całkowity; blok przedsionkowo-komorowy II stopnia i blok przedsionkowo-komorowy I stopnia występują, od- powiednio, w 16\% i 12\% przypadków [1, 7]. Podkreśla się dużą zmienność stopnia bloku przedsionkowo-komorowego - czasami w ciągu kilku minut dochodzi do progresji lub ustępowania bloku [4]. W 1/3 przypadków bradyarytmia wymaga zastosowania czasowej stymulacji serca. Zaleca się hospitalizować i monitorować pacjentów nie tylko z blokiem przedsionkowo-komorowym III i II stopnia, lecz także 
z blokiem przedsionkowo-komorowym I stopnia, gdy odstęp PQ przekracza 300 ms [8].

W omawianym przypadku pacjent był monitorowany na sali intensywnego nadzoru kardiologicznego i zabezpieczony elektrodami do stymulacji przezskórnej. Mimo wolnej czynności komór - okresowo 20/min - nie miał objawów wynikających z bradyarytmii i tym samym uniknął czasowej stymulacji endokawitarnej.

Pacjenci z narządową postacią boreliozy są leczeni antybiotykami podawanymi dożylnie. W przypadku LC zaleca się ceftriakson, cefotaksym lub penicylinę $\mathrm{G}$ przez 14-28 dni. Zaburzenia przewodzenia przedsionkowo-komorowego ustępują szybko - w ciągu 1-3 dni, rzadko utrzymują się dłużej niż tydzień i zwykle jest to wtedy blok przedsionkowo-komorowy I stopnia [4, 7]. Część badaczy sugeruje, że antybiotykoterapia nie wpływa na obraz kliniczny LC, ponieważ w naturalnym przebiegu choroby blok przedsionkowo-komorowym ustępuje niemal w każdym przypadku [4]. Przeważa jednak pogląd, że zastosowanie antybiotyku skraca czas utrzymywania się zaburzeń przewodzenia przedsionkowo-komorowego. Wiadomo również, że u pacjentów leczonych antybiotykiem z powodu erythema migrans nie rozwija się LC [9]. Zdarza się, że pacjentom z LC, w związku z opóźnieniem właściwego rozpoznania, wszczepia się rozrusznik serca. W dalszej obserwacji nie stwierdza się u nich zaburzeń przewodzenia przedsionkowo-komorowego, a odsetek stymulacji jest znikomy [10].

$\mathrm{U}$ opisywanego chorego leczenie ceftriaksonem rozpoczęto z chwilą podejrzenia zajęcia mięśnia sercowego, jeszcze przed otrzymaniem wyników badań serologicznych. Blok przedsionkowo-komorowy całkowity i zaawansowany blok przedsionkowo-komorowy II stopnia ustąpiły w 2 . dobie leczenia. Blok przedsionkowo-komorowy I stopnia utrzymywał się przez kolejne 2 tygodnie, początkowo z odstępem PQ wynoszącym 0,5 s. Od 3. tygodnia leczenia u pacjenta nie rejestrowano zaburzeń przewodzenia przedsionkowo-komorowego.

\section{Podsumowanie}

Boreliozowe zapalenie mięśnia sercowego należy uwzględniać w diagnostyce różnicowej przyczyn bloku przedsionkowo-komorowego, zwłaszcza że stanowi jego potencjalnie odwracalną przyczynę i często dotyczy osób młodych.

\section{Konflikt interesów}

Autorzy nie zgłaszają konfliktu interesów.

\section{Abstract}

We present the case of a 32-year-old man with Lyme carditis and a complete atrioventricular block who was successfully treated four weeks with ceftriaxone. Atrioventricular block resolved completely and now after two years of follow-up he remains healthy with no atrioventricular conduction disturbances in a 24-hour ECG monitoring.

Key words: Lyme disease, Lyme carditis, atrioventricular block

(Folia Cardiologica 2015; 10, 6: 442-447)

\section{Piśmiennictwo}

1. Van der Linde M.R. Lyme carditis: clinical characteristics of 105 cases. Scand. J. Infect. Dis. Suppl 1991; 77: 81-84.

2. Rostoff P., Konduracka E., El Massri N. i wsp. Boreliozowe zapalenie serca manifestujące się jako ostry zespół wieńcowy. Kardiol. Pol. 2008; 66: 420-425.

3. Konopka M., Kuch M., Braksator W. i wsp. Unclassified cardiomyopathy or Lyme carditis? A three year follow-up. Kardiol. Pol. 2013; 71: 283-285.

4. Steere A.C., Batsford W.P., Weiberg M. i wsp. Lyme carditis: cardiac abnormalities of Lyme disease. Ann. Intern. Med. 1980; 93: 8-16.

5. Wasiluk A., Zalewska-Szajda B., Waszkiewicz N. i wsp. Lyme disease: etiology, pathogenesis, clinical courses, diagnostics and treatment. Prog. Health Sci. 2011; 1: 179-186.

6. Murray T., Shapiro E.D. Lyme disease. Clin. Lab. Med. 2010; 30: 311-328.
7. McAlister H.F., Klementowicz P.T., Andrews C. i wsp. Lyme carditis: an important cause of reversible heart block. Ann. Intern. Med. 1989; 110: 339-345.

8. Wormser G.P., Dattwyler R.J., Shapiro E.D. i wsp. The clinical assessment, treatment and prevention of lyme disease, human granulocytic anaplasmosis and babesiosis: clinical practice guidelines by the Infectious Diseases Society of America. Clin. Infect. Dis. 2006; 43: 1089-1134.

9. Sangha 0., Phillips C.B., Fleischmann K.E. i wsp. Lack of cardiac manifestations among patients with previously treated Lyme disease. Ann. Intern. Med. 1998; 128: 346-353.

10. Elikowski W., Małek M., Flieger J. i wsp. Całkowity blok przedsionkowo-komorowy a borelioza z Lyme: opis dwóch różnych przypadków i przegląd piśmiennictwa. Kardiol. Pol. 2007; 65: 565-570. 